\title{
Synthesis and anthelmintic activity of some novel 2-substituted-4,5-diphenyl imidazoles
}

SATYAJIT DUTTA

Department of Pharmacy, IIMT College of Medical Sciences, 'O'Pocket, Ganga Nagar, Mawana Road, Meerut-250001 Uttar Pradesh, India

\begin{abstract}
A series of 2-substituted-4,5-diphenyl imidazoles 1a-j were synthesized by refluxing benzil with different substituted aldehydes in the presence of ammonium acetate and glacial acetic acid. Structures of the synthesized compounds were confirmed on the basis of IR, ${ }^{1} \mathrm{H}$ NMR and mass spectral data. Compounds $1 \mathbf{a}-\mathbf{j}$ were screened for anthelmintic activity. Test results revealed that compounds showed paralysis time of 0.24 to $1.54 \mathrm{~min}$ and death time of 0.39 to $4.40 \mathrm{~min}$ while the standard drugs albendazole and piperazine citrate showed paralysis time of 0.54 and $0.58 \mathrm{~min}$ and death time of 2.16 and $2.47 \mathrm{~min}$, respectively, at the same concentration of $1 \%(\mathrm{~m} / \mathrm{V})$. Five compounds, 2-[2-hydroxyphenyl]-4,5-diphenyl imidazole (1b), 2-[3-methoxyphenyl]-4,5-diphenyl imidazole (1c), 2-[2-phenylethenyl]-4,5- diphenyl imidazole (1e), 2-[4-fluorophenyl]-4,5-diphenyl imidazole (19) and 2-[3-nitrophenyl]-4,5-diphenyl imidazole (1h) showed significant anthelmintic activity compared to the standard drugs.
\end{abstract}

Keywords: 2-substituted-4,5-diphenyl imidazoles, anthelmintic, antiparasitic

There are two important types of worm infections, those in which the worms live in the host alimentary canal and those in which the worms live in other tissues of the host body. Common examples of worms (1) in the host body (alimentary canal) are the tape worm, intestinal round worm, trematodes or flukes, tissue round worm, etc. Various diseases caused by helminthes are ascariasis, trichirians, hook worm and tape worm infection, thread worm infection, schistosomiasis, giardial infection (2).

During the last decades, compounds bearing heterocyclic nuclei have received much attention due to their chemotherapeutic value in the development of novel anthelmintics. Imidazole derivatives have a wide range of biological activities, including analgesic and anti-inflammatory $(3,4)$, antiparasitic (5), antitubercular $(6,7)$, antiviral $(8,9)$, anticonvulsant (10) and insecticidal activities (11). In view of such reports, the present work is aimed at the synthesis of various 2-substituted-4,5-diphenyl imidazoles and evaluation of their anthelmintic activity.

Correspondence; e-mail: sanku6@gmail.com 


\section{EXPERIMENTAL}

The chemicals and solvents used for the experimental work were commercially procured from E. Merck, India, CDH, s.d. Fine Chem, India and Qualigens, India. Silica gel $G$ used for analytical chromatography (TLC) was obtained from E. Merck.

Melting points were determined in an open glass capillary using a Kjeldahl flask containing paraffin and are uncorrected. The proton magnetic resonance spectra $\left({ }^{1} \mathrm{H}\right.$ NMR) were recorded on a Bruker $300 \mathrm{MHz}$ instrument (Bruker, Germany) in dimethyl sulfoxide- $d_{6} / \mathrm{CDCl}_{3}$ using tetramethylsilane as internal standard. Chemical shifts $(\delta)$ are expressed in ppm. The infrared spectra of compounds were recorded in $\mathrm{KBr}$ on a FTIR-8400S, Fourier Transform (Shimadzu), Japan infrared spectrophotometer. Mass spectra were recorded on LC-MS/MS (API-4000 TM), Applied BioSystems, MDS SCIEX (Canada). Elemental analyses were performed on a Perkin-Elmer model 240c analyzer (Per-

Table I. Physicochemical data of synthesized 2-substituted-4,5-diphenyl inidazoles

\begin{tabular}{|c|c|c|c|c|c|c|c|c|}
\hline \multirow{2}{*}{$\begin{array}{l}\text { Compd. } \\
\text { No. }\end{array}$} & \multirow[t]{2}{*}{$\mathrm{R}$} & \multirow{2}{*}{$\begin{array}{l}\text { Mol. formula } \\
\qquad\left(M_{\mathrm{r}}\right)^{\mathrm{a}}\end{array}$} & \multirow{2}{*}{$\begin{array}{l}\text { M.p. } \\
\left({ }^{\circ} \mathrm{C}\right)^{\mathrm{b}}\end{array}$} & \multirow{2}{*}{$R_{\mathrm{f}}$ value $^{\mathrm{c}}$} & \multirow{2}{*}{$\begin{array}{c}\text { Yield } \\
(\%)\end{array}$} & \multicolumn{3}{|c|}{$\begin{array}{l}\text { Elemental analysis } \\
\text { Calcd./found (\%) }\end{array}$} \\
\hline & & & & & & $\mathrm{C}$ & $\mathrm{H}$ & $\mathrm{N}$ \\
\hline \multirow{2}{*}{$1 \mathrm{a}$} & \multirow{2}{*}{ Phenyl } & \multirow{2}{*}{$\begin{array}{l}\mathrm{C}_{21} \mathrm{H}_{16} \mathrm{~N}_{2} \\
(296.21)\end{array}$} & \multirow{2}{*}{$265-267$} & \multirow{2}{*}{0.96} & \multirow{2}{*}{80} & 82.49 & 5.48 & 12.03 \\
\hline & & & & & & 82.74 & 5.62 & 11.98 \\
\hline \multirow{2}{*}{$1 b$} & \multirow{2}{*}{ 2-Hydroxyphenyl } & \multirow{2}{*}{$\begin{array}{l}\mathrm{C}_{21} \mathrm{H}_{16} \mathrm{~N}_{2} \mathrm{O} \\
(312.20)\end{array}$} & \multirow{2}{*}{$210-212$} & \multirow{2}{*}{0.94} & \multirow{2}{*}{72} & 78.16 & 5.42 & 11.89 \\
\hline & & & & & & 78.50 & 5.12 & 12.23 \\
\hline \multirow{2}{*}{ 1c } & \multirow{2}{*}{ 3-Methoxyphenyl } & \multirow{2}{*}{$\begin{array}{c}\mathrm{C}_{22} \mathrm{H}_{18} \mathrm{~N}_{2} \mathrm{O} \\
(326.21)\end{array}$} & \multirow{2}{*}{$252-255$} & \multirow{2}{*}{0.85} & \multirow{2}{*}{54} & 70.66 & 5.19 & 9.56 \\
\hline & & & & & & 70.29 & 5.27 & 9.85 \\
\hline \multirow{2}{*}{ 1d } & \multirow{2}{*}{$\begin{array}{l}\text { 4-Hydroxy-3- } \\
\text {-methoxyphenyl }\end{array}$} & \multirow{2}{*}{$\begin{array}{c}\mathrm{C}_{22} \mathrm{H}_{18} \mathrm{~N}_{2} \mathrm{O}_{2} \\
(342.20)\end{array}$} & \multirow{2}{*}{$245-247$} & \multirow{2}{*}{0.91} & \multirow{2}{*}{68} & 68.56 & 5.18 & 8.00 \\
\hline & & & & & & 68.38 & 5.22 & 7.85 \\
\hline \multirow{2}{*}{ 1e } & \multirow{2}{*}{ 2-Phenylethenyl } & \multirow{2}{*}{$\begin{array}{l}\mathrm{C}_{23} \mathrm{H}_{18} \mathrm{~N}_{2} \\
(322.23)\end{array}$} & $140-142$ & & & 73.00 & 4.79 & 22.21 \\
\hline & & & $140-142$ & 0.82 & 56 & 73.26 & 4.87 & 22.73 \\
\hline If & 2-Chloronhenyl & $\mathrm{C}_{21} \mathrm{H}_{15} \mathrm{~N}_{2} \mathrm{Cl}$ & $191-193$ & & & 78.28 & 5.21 & 10.93 \\
\hline & 2-chiorophenyl & (330.66) & 191-193 & 0.93 & 61 & 78.43 & 5.12 & 11.24 \\
\hline 10 & 4-Fluorophenvl & $\mathrm{C}_{21} \mathrm{H}_{15} \mathrm{~N}_{2} \mathrm{~F}$ & $86-88$ & 0.97 & & 77.26 & 5.32 & 10.14 \\
\hline & & $(314.20)$ & $86-88$ & 0.97 & 48 & 77.43 & 5.29 & 10.52 \\
\hline $1 \mathrm{~h}$ & 3-Nitrophenvl & $\mathrm{C}_{21} \mathrm{H}_{15} \mathrm{~N}_{3} \mathrm{O}_{2}$ & 105-107 & 089 & 81 & 76.46 & 4.32 & 12.11 \\
\hline & & $(341.19)$ & & & & 76.73 & 4.59 & 12.32 \\
\hline $1 \mathrm{i}$ & $\mathrm{H}$ & $\mathrm{C}_{15} \mathrm{H}_{12} \mathrm{~N}_{2}$ & $88-90$ & 0.98 & 32 & 70.26 & 5.52 & 24.22 \\
\hline & & $(220.15)$ & $88-90$ & 0.98 & 32 & 69.93 & 5.23 & 24.67 \\
\hline $1 \mathrm{i}$ & Methyl & $\mathrm{C}_{16} \mathrm{H}_{14} \mathrm{~N}_{2}$ & $76-78$ & 0.95 & 37 & 71.58 & 6.43 & 21.99 \\
\hline 1] & Mletnyl & $(234.16)$ & $76-18$ & 0.95 & 37 & 71.21 & 6.28 & 21.17 \\
\hline
\end{tabular}

a Solvent for crystallization: ethanol.

b Melting point of the compounds at decomposition.

c Solvent system: ethanol/methanol (8:2).

e Elemental analyses for $\mathrm{C}, \mathrm{H}, \mathrm{N}$ were within $\pm 0.4 \%$ of the theoretical value. 
kin Elmer, USA). The physicochemical and spectral data of the compounds are listed in Tables I and II, respectively.

\section{Synthesis}

2-Substituted-4,5-diphenyl imidazoles (1a-j). - Benzil (5.25 g, $25 \mathrm{mmol})$, and ammonium acetate (10 g) were dissolved in glacial acetic acid and then refluxed for 3-5 h. After refluxing, the reaction mixture was left overnight and filtered to remove any precipitate that may be present. Water $(300 \mathrm{~mL})$ was then added to the filtrate and the precipitate formed was collected. The filtrate was neutralized with ammonium hydroxide and the

Table II. Spectral characterization of synthesized 2-substituted-4,5-diphenyl inidazoles

\begin{tabular}{|c|c|c|c|}
\hline $\begin{array}{l}\text { Compd. } \\
\text { No. }\end{array}$ & FT-IR $\left(\mathrm{KBr}, \mathrm{cm}^{-1}\right)$ & ${ }^{1} \mathrm{H}$ NMR $\left(\mathrm{DMSO}-d_{6}, \delta, \mathrm{ppm}\right)$ & Mass $(m / z)$ \\
\hline 1a & $\begin{array}{l}3447(\mathrm{~N}-\mathrm{H}), 1699 \\
(\mathrm{C}=\mathrm{N}), 3085(\mathrm{C}-\mathrm{H}) \\
1536(\mathrm{C}=\mathrm{C} \text { aromatic })\end{array}$ & $\begin{array}{l}7.9\left(\mathrm{~d}, 2 \mathrm{H}, \mathrm{H}-2^{\prime} \text { and } \mathrm{H}-6^{\prime}\right), 7.48\left(\mathrm{~d}, 4 \mathrm{H}, \mathrm{H}-2^{\prime \prime},\right. \\
\left.\mathrm{H}-6^{\prime \prime} \text { and } \mathrm{H}-6^{\prime \prime \prime}\right), 7.4-7.3(\mathrm{~m}, 9 \mathrm{H} \text {, aromatic } \\
\text { protons })\end{array}$ & $296\left(\mathrm{M}^{+}\right)$ \\
\hline $1 b$ & $\begin{array}{l}3449(\mathrm{~N}-\mathrm{H}), 1674 \\
(\mathrm{C}=\mathrm{N}), 3064(\mathrm{C}-\mathrm{H}) \\
1594(\mathrm{C}=\mathrm{C} \text { aromatic })\end{array}$ & $\begin{array}{l}12.8(\mathrm{~s}, 1 \mathrm{H}, \mathrm{OH}), 8.06\left(\mathrm{~d}, 1 \mathrm{H}, \mathrm{H}-6^{\prime}\right), 7.7-7.2 \\
(\mathrm{~m}, 1 \mathrm{H}, \text { aromatic protons }), 6.93\left(\mathrm{t}, 2 \mathrm{H}, \mathrm{H}-4^{\prime} \text { and }\right. \\
\left.\mathrm{H}-5^{\prime}\right)\end{array}$ & $312\left(\mathrm{M}^{+}\right)$ \\
\hline 1c & $\begin{array}{l}3453(\mathrm{~N}-\mathrm{H}), 1643 \\
(\mathrm{C}=\mathrm{N}), 3066(\mathrm{C}-\mathrm{H}) \\
1485(\mathrm{C}=\mathrm{C} \text { aromatic })\end{array}$ & $\begin{array}{l}6.97\left(\mathrm{~d}, 1 \mathrm{H}, \mathrm{H}-5^{\prime}\right), 7.31\left(\mathrm{~d}, 2 \mathrm{H}, \mathrm{H}-3^{\prime \prime} \text { and } \mathrm{H}-5^{\prime \prime}\right), \\
7.49\left(\mathrm{~d}, 2 \mathrm{H}, \mathrm{H}-2^{\prime \prime} \text { and } \mathrm{H}-6^{\prime \prime}\right), 7.34\left(\mathrm{~d}, 2 \mathrm{H}, \mathrm{H}-3^{\prime \prime \prime}\right. \\
\left.\text { and } \mathrm{H}-5^{\prime \prime \prime}\right), 3.89\left(\mathrm{~s}, 1 \mathrm{H}, \mathrm{OCH}_{3}\right)\end{array}$ & $326\left(\mathrm{M}^{+}\right)$ \\
\hline $1 d$ & $\begin{array}{l}3453(\mathrm{~N}-\mathrm{H}), 1676 \\
(\mathrm{C}=\mathrm{N}), 3064(\mathrm{C}-\mathrm{H}) \\
1594(\mathrm{C}=\mathrm{C} \text { aromatic })\end{array}$ & $\begin{array}{l}\text { 7.9-7.2 }(\mathrm{m}, 12 \mathrm{H}, \text { aromatic protons }), 6.87(\mathrm{~d} \\
\left.1 \mathrm{H}, \mathrm{H}-5^{\prime}\right), 3.8\left(\mathrm{~s}, 1 \mathrm{H}, \mathrm{OCH}_{3}\right), 3.4(\mathrm{~s}, 1 \mathrm{H}, \mathrm{OH})\end{array}$ & $342\left(\mathrm{M}^{+}\right)$ \\
\hline 1e & $\begin{array}{l}3446(\mathrm{~N}-\mathrm{H}), 1676 \\
(\mathrm{C}=\mathrm{N}), 3065(\mathrm{C}-\mathrm{H}) \\
1594(\mathrm{C}=\mathrm{C} \text { aromatic })\end{array}$ & $\begin{array}{l}7.9\left(\mathrm{~d}, 4 \mathrm{H}, \mathrm{H}-2^{\prime \prime}, \mathrm{H}-6^{\prime \prime}, \mathrm{H}-2^{\prime \prime \prime} \text { and } \mathrm{H}-6^{\prime \prime \prime}\right), 7.8(\mathrm{~d}, \\
\left.2 \mathrm{H}, \mathrm{H}-2^{\prime} \text { and } \mathrm{H}-6^{\prime}\right), 7.6-7.2(\mathrm{~m}, 10 \mathrm{H}, \text { aromatic } \\
\text { protons and alkenyl proton), } 7.1(\mathrm{~d}, 1 \mathrm{H},=\mathrm{CH})\end{array}$ & $322\left(\mathrm{M}^{+}\right)$ \\
\hline 1f & $\begin{array}{l}3449(\mathrm{~N}-\mathrm{H}), 1673 \\
(\mathrm{C}=\mathrm{N}), 3063(\mathrm{C}-\mathrm{H}) \\
1592(\mathrm{C}=\mathrm{C} \text { aromatic })\end{array}$ & $\begin{array}{l}7.57\left(\mathrm{~m}, 4 \mathrm{H}, \mathrm{H}-3^{\prime}, \mathrm{H}-4^{\prime}, \mathrm{H}-5^{\prime} \text { and } \mathrm{H}-6^{\prime}\right), 7.4-7.3 \\
(\mathrm{~m}, 10 \mathrm{H} \text {, aromatic protons })\end{array}$ & $330\left(\mathrm{M}^{+}\right)$ \\
\hline $1 \mathrm{~g}$ & $\begin{array}{l}3423(\mathrm{~N}-\mathrm{H}), 1660 \\
(\mathrm{C}=\mathrm{N}), 3063(\mathrm{C}-\mathrm{H}) \\
1492(\mathrm{C}=\mathrm{C} \text { aromatic })\end{array}$ & $\begin{array}{l}7.35\left(\mathrm{~d}, 2 \mathrm{H}, \mathrm{H}-2^{\prime} \text { and } \mathrm{H}-6^{\prime}\right), 7.01\left(\mathrm{~d}, 2 \mathrm{H}, \mathrm{H}-3^{\prime}\right. \\
\left.\text { and } \mathrm{H}-5^{\prime}\right), 7.46\left(\mathrm{~d}, 2 \mathrm{H}, \mathrm{H}-2^{\prime \prime} \text { and H-6"), } 7.31(\mathrm{~d},\right. \\
\left.2 \mathrm{H}, \mathrm{H}-3^{\prime \prime} \text { and } \mathrm{H}-5^{\prime \prime}\right), 7.04\left(\mathrm{~s}, 1 \mathrm{H}, \mathrm{H}-4^{\prime \prime}\right), 7.48(\mathrm{~d}, \\
2 \mathrm{H}, \mathrm{H}-2^{\prime \prime \prime} \text { and H-6"'), } 7.3\left(\mathrm{~d}, 2 \mathrm{H}, \mathrm{H}-3^{\prime \prime \prime} \text { and }\right. \\
\left.\mathrm{H}-5^{\prime \prime \prime}\right), 7.28\left(\mathrm{~s}, 1 \mathrm{H}, \mathrm{H}-4^{\prime \prime \prime}\right)\end{array}$ & $314\left(\mathrm{M}^{+}\right)$ \\
\hline $1 \mathrm{~h}$ & $\begin{array}{l}3452(\mathrm{~N}-\mathrm{H}), 1661 \\
(\mathrm{C}=\mathrm{N}), 3065(\mathrm{C}-\mathrm{H}) \\
1594(\mathrm{C}=\mathrm{C} \text { aromatic })\end{array}$ & $\begin{array}{l}6.94\left(\mathrm{~d}, 1 \mathrm{H}, \mathrm{H}-5^{\prime}\right) 7.54\left(\mathrm{~d}, 2 \mathrm{H}, \mathrm{H}-2^{\prime \prime} \text { and } \mathrm{H}-6^{\prime \prime}\right) \\
7.56\left(\mathrm{~d}, 2 \mathrm{H}, \mathrm{H}-2^{\prime \prime \prime} \text { and } \mathrm{H}-6^{\prime \prime \prime}\right), 7.39(\mathrm{t}, 6 \mathrm{H}, \\
\text { aromatic protons })\end{array}$ & $341\left(\mathrm{M}^{+}\right)$ \\
\hline $1 \mathbf{i}$ & $\begin{array}{l}3444(\mathrm{~N}-\mathrm{H}), 1658 \\
(\mathrm{C}=\mathrm{N}), 3063(\mathrm{C}-\mathrm{H}) \\
1460(\mathrm{C}=\mathrm{C} \text { aromatic })\end{array}$ & $7.4-7.9(\mathrm{~m}, 10 \mathrm{H}$, aromatic protons $)$ & $220\left(\mathrm{M}^{+}\right)$ \\
\hline $1 \mathbf{j}$ & $\begin{array}{l}3441(\mathrm{~N}-\mathrm{H}), 1650 \\
(\mathrm{C}=\mathrm{N}), 3062(\mathrm{C}-\mathrm{H}) \\
1450(\mathrm{C}=\mathrm{C} \text { aromatic })\end{array}$ & $\begin{array}{l}8.16\left(\mathrm{~d}, 2 \mathrm{H}, \mathrm{H}-2^{\prime} \text { and } \mathrm{H}-6^{\prime}\right) 7.95\left(\mathrm{~d}, 2 \mathrm{H}, \mathrm{H}-3^{\prime}\right. \\
\left.\text { and } \mathrm{H}-5^{\prime}\right), 7.54\left(\mathrm{~d}, 2 \mathrm{H}, \mathrm{H}-2^{\prime \prime} \text { and } \mathrm{H}-6^{\prime \prime}\right), 3.3 \\
\left(\mathrm{~s}, \mathrm{H}, \mathrm{CH}_{3}\right)\end{array}$ & $234\left(\mathrm{M}^{+}\right)$ \\
\hline
\end{tabular}


second crop of the solid was collected. The two crops of the precipitate were combined, dried and recrystallized from ethanol (12).

\section{Pharmacology}

Anthelmintic activity. - The newly synthesized compounds were tested for anthelmintic activity according to the method described by Kuppast (13). Pheretima posthuma (earth worms obtained from Shibpur Botanical Garden, Kolkata, India) of nearly equal size $(6 \pm 1 \mathrm{~cm})$ were selected randomly for the present study. The worms were acclimatized to laboratory conditions before experimentation. The earthworms were divided into four groups of six earth worms each. Albendazole and piperazine citrate diluted with normal saline solution to obtain $0.1,0.2,0.5$ and $1 \%(\mathrm{~m} / \mathrm{V})$ served as standard and were poured into Petri dishes. The synthesized compounds were dissolved in minimal quantity of ethanol and diluted to prepare four concentrations of $0.1,0.2,0.5$ and $1 \%(\mathrm{~m} / \mathrm{V})$ of each compound. Normal saline served as a control. The time taken for complete paralysis and death was recorded. The mean paralysis time and mean lethal time were calculated for each compound (each reading was taken in triplicate). The time taken for worms to become motionless was noted as paralysis time. To ascertain death, each worm was frequently subjected to external stimuli that stimulate and induce movement in earth worms, if alive.

Table III. Anthelmintic activity of synthesized 2-substituted-4,5-diphenyl inidazoles

\begin{tabular}{|c|c|c|c|c|c|c|c|c|}
\hline \multirow{3}{*}{ Compound } & \multicolumn{4}{|c|}{ Time for paralysis $(\min )^{\mathrm{a}}$} & \multicolumn{4}{|c|}{ Time for death $(\min )^{\mathrm{a}}$} \\
\hline & \multicolumn{4}{|c|}{ Concentration $(\%)$} & \multicolumn{4}{|c|}{ Concentration (\%) } \\
\hline & 0.1 & 0.2 & 0.5 & 1.0 & 0.1 & 0.2 & 0.5 & 1.0 \\
\hline 1a & $3.3 \pm 0.6$ & $2.3 \pm 0.1$ & $1.3 \pm 0.2$ & $1.3 \pm 0.2$ & $7.1 \pm 1.0$ & $5.1 \pm 0.2$ & $3.1 \pm 0.2$ & $2.3 \pm 0.2$ \\
\hline $1 b$ & $1.3 \pm 0.1$ & $1.1 \pm 0.0_{2}$ & $0.6 \pm 0.2$ & $0.5 \pm 0.1$ & $3.0 \pm 0.2$ & $2.2 \pm 0.1$ & $2.2 \pm 0.2$ & $1.6 \pm 0.3$ \\
\hline 1c & $1.3 \pm 0.1$ & $0.4 \pm 0.0_{2}$ & $0.3 \pm 0.0_{1}$ & $0.2 \pm 0.0_{1}$ & $5.4 \pm 0.2$ & $1.4 \pm 0.1$ & $1.1 \pm 0.0_{4}$ & $0.4 \pm 0.0_{1}$ \\
\hline $1 d$ & $3.1 \pm 0.0_{4}$ & $2.4 \pm 0.1$ & $2.3 \pm 0.2$ & $1.1 \pm 0.2$ & $8.0 \pm 0.2$ & $5.6 \pm 0.2$ & $4.0 \pm 0.4$ & $2.2 \pm 0.0_{3}$ \\
\hline $1 e$ & $4.1 \pm 0.4$ & $2.3 \pm 0.1$ & $1.0 \pm 0.2$ & $0.5 \pm 0.0_{1}$ & $20.5 \pm 0.3$ & $8.5 \pm 0.4$ & $2.4 \pm 0.1$ & $1.3 \pm 0.0_{3}$ \\
\hline 1f & $2.5 \pm 0.3$ & $2.1 \pm 0.2$ & $1.5 \pm 0.0_{3}$ & $1.2 \pm 0.1$ & $6.1 \pm 0.3$ & $4.3 \pm 0.1$ & $3.2 \pm 0.1$ & $2.4 \pm 0.1$ \\
\hline $1 \mathrm{~g}$ & $2.1 \pm 0.2$ & $1.5 \pm 0.2$ & $1.2 \pm 0.1$ & $0.6 \pm 0.2$ & $8.5 \pm 0.3$ & $5.0 \pm 0.2$ & $4.1 \pm 0.0_{4}$ & $2.1 \pm 0.0_{4}$ \\
\hline 1h & $1.3 \pm 0.2$ & $1.1 \pm 0.2$ & $0.3 \pm 0.0_{3}$ & $0.3 \pm 0.1$ & $4.2 \pm 0.3$ & $2.3 \pm 0.5$ & $1.2 \pm 0.1$ & $1.1 \pm 0.2$ \\
\hline $1 \mathrm{i}$ & $4.4 \pm 0.3$ & $3.1 \pm 0.4$ & $2.1 \pm 0.2$ & $1.5 \pm 0.3$ & $11.2 \pm 0.5$ & $9.3 \pm 0.1$ & $4.6 \pm 0.4$ & $4.4 \pm 0.1$ \\
\hline $1 \mathbf{j}$ & $4.6 \pm 0.4$ & $3.1 \pm 0.4$ & $2.3 \pm 0.1$ & $1.3 \pm 0.1$ & $23.4 \pm 0.7$ & $13.1 \pm 1.4$ & $6.3 \pm 0.1$ & $3.1 \pm 0.4$ \\
\hline $\begin{array}{c}\text { Negative control } \\
\text { (dimethyl } \\
\text { sulphoxide) }\end{array}$ & $24.5 \pm 0.1$ & $22.1 \pm 0.1$ & $20.1 \pm 0.02$ & $17.2 \pm 0.2$ & $38.1 \pm 0.1$ & $37.1 \pm 0.2$ & $34.2 \pm 0.2$ & $30.1 \pm 0.1$ \\
\hline Albendazole & $1.4 \pm 0.1$ & $1.3 \pm 0.1$ & $1.1 \pm 0.03$ & $0.5 \pm 0.02$ & $4.1 \pm 0.2$ & $4.0 \pm 0.2$ & $3.6 \pm 0.2$ & $2.2 \pm 0.03$ \\
\hline Piperazine citrate & $2.1 \pm 0.03$ & $1.5 \pm 0.2$ & $1.3 \pm 0.01$ & $0.6 \pm 0.3$ & $6.0 \pm 0.3$ & $4.4 \pm 0.4$ & $4.0 \pm 0.03$ & $2.5 \pm 0.03$ \\
\hline
\end{tabular}

\footnotetext{
a Mean \pm SEM, $n=6$.
} 


\section{RESULTS AND DISCUSSION}

2-Substituted-4,5-diphenyl imidazoles 1a-j were synthesized by refluxing benzil with different substituted aldehydes in the presence of ammonium acetate and glacial acetic acid. The synthetic pathway is presented in Scheme 1. The IR spectra of compounds 1a-j revealed the presence of absorption bands from 3423 to $3453 \mathrm{~cm}^{-1}$ for the NH group, from 1643 to $1699 \mathrm{~cm}^{-1}$ due to $\mathrm{C}=\mathrm{N}$, from 3062 to $3085 \mathrm{~cm}^{-1}$ for $\mathrm{C}-\mathrm{H}$ and from 1450 to $1594 \mathrm{~cm}^{-1}$ for $\mathrm{C}=\mathrm{C}$ aromatic stretching vibrations. The ${ }^{1} \mathrm{H}$ NMR spectra of compounds 1a-j showed two doublets from $\delta 7.01$ to $7.8 \mathrm{ppm}$ for aromatic protons, one singlet at $\delta 12.9 \mathrm{ppm}, \delta 3.89 \mathrm{ppm}$ and $\delta 3.4 \mathrm{ppm}$ for $-\mathrm{OH},-\mathrm{CH}_{3}$ and $-\mathrm{OH}$ protons of compounds $\mathbf{1 b}, \mathbf{1 c}$ and $\mathbf{1 d}$, respectively, confirming the formation of compounds $\mathbf{1 a} \mathbf{a} \mathbf{j}$. The mass spectra of compounds $\mathbf{1} \mathbf{a}-\mathbf{j}$ showed molecular ion peaks $\mathbf{M}^{+}$at $m / z$ corresponding to their respective molecular masses, which is in agreement with their respective molecular formulas (Tables I and II).

The anthelmintic activity of all compounds was examined using reported procedures (13). The anthelmintic evaluation of compounds $1 \mathbf{a}-\mathbf{j}$ in earth worms at four concentrations, i.e., $0.1,0.2,0.5$ and $1 \%(m / V)$, is given in Table III together with experimental data on the drugs used as standards, albendazole and piperazine citrate. A closer inspec-

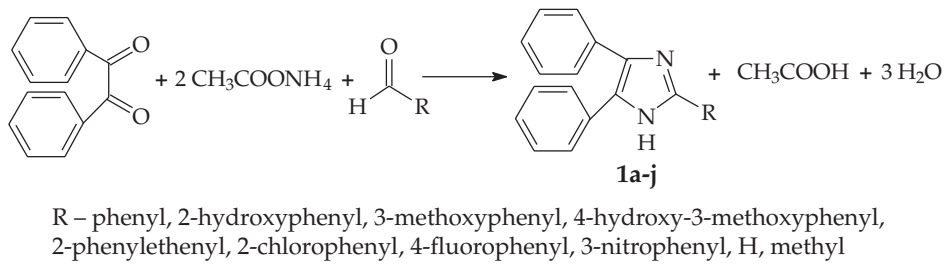

Scheme 1

tion of the data from the table indicates that compounds $\mathbf{1 b}, \mathbf{1 c}, \mathbf{1 e}, \mathbf{1 g}$ and $\mathbf{1 h}$ have higher activity than other compounds, which was confirmed by their paralysis time of 0.46 , $0.24,0.51,0.56$ and $0.26 \mathrm{~min}$, respectively, and death time of 1.57, 0.39, 1.28, 2.08 and 1.07 min, respectively, at a concentration of $1 \% \mathrm{~m} / \mathrm{V}$. All other compounds possess low anthelmintic activity.

Compounds with hydroxy and methoxy substituents at the ortho and meta position of the phenyl ring at the 2 nd position of compounds $\mathbf{1 b}$ and $\mathbf{1 c}$ led to a considerable increase in activity. The presence of the electron donating methoxy group and electron withdrawing nitro group at meta position of the phenyl ring resulted in an increase in activity of compounds $\mathbf{1 c}$ and $\mathbf{1 h}$, respectively. Fluorine at para position of the phenyl ring provided activity to compound $\mathbf{1 g}$. 


\section{CONCLUSIONS}

Various 2-substituted-4,5-diphenyl imidazole derivatives were prepared with the objective of developing better anthelmintic molecules. Among these derivatives, 2-[2-hydroxyphenyl]-4,5-diphenyl imidazole (1b), 2-[3-methoxyphenyl]-4,5-diphenyl imidazole (1c), 2-phenylethenyl-4,5-diphenyl imidazole (1e), 2-[4-fluorophenyl]-4,5-diphenyl imidazole (19) and 2-[3-nitrophenyl]-4,5-diphenyl imidazole (1h) were found to have improved activity compared to albendazole and piperazine citrate. 2-Hydroxyphenyl, 3-methoxyphenyl, 2-phenylethenyl, 4-fluorophenyl and 3-nitrophenyl groups at the 2nd position in imidazole derivatives seem to be resposible for high activity.

Acknowledgements. - The author is grateful to the Himalayan Pharmacy Institute (Sikkim) and IIMT College of Medical Sciences (Meerut) for providing research facilities to pursue this work.

\section{REFERENCES}

1. H. P. Rang, M. M. Dale, J. M. Ritter and P. K. Moore, Anthelmintic Drugs in Rang and Dale's Pharmacology, $5^{\text {th }}$ ed., Churchill Livingstone, New York 2003, pp. 687-692.

2. K. D. Tripathi, Anthelmintics, Essential of Medical Pharmacology (Ed. M. Tripathy), $5^{\text {th }}$ ed., Jaypee Brothers Medical Publishers (P) Ltd., New Delhi 2004, pp. 759-766.

3. S. Drabu, N. Kumar and S. Munirajan, Synthesis and anti-inflammatory activity of some 3-substituted indolo-2,3-imidazoles, Indian J. Heterocycl. Chem. 15 (2005) 195-196.

4. S. Dutta, G. Mariappan, B. P. Saha and P. K. Kar, Analgesic and anti-inflammatory activity of 2-substituted 4,5-diphenyl imidazole, Adv. Pharmacol. Toxicol. 9 (2008) 39-44.

5. L. Quattara, M. Debaert and R. Cavier, Synthesis and antiparasitic activity of new nitro-5-imidazole derivatives, Farm. Ed. Sci. 42 (1987) 449-456.

6. S. R. Pattan, V. V. K. Reddy, F. V. Manvi, B. G. Desai and A. R. Bhat, Synthesis of N-3-(4-(4-chlorophenyl-thiazol-2-yl)-(2-(amino)methyl)-quinazoline-4(3H)-one and their derivatives for antitubercular activity, Indian J. Chem. 45B (2006) 1778-1781.

7. P. Gupta, S. Hameed and R. Jain, Ring-substituted imidazoles as a new class of anti-tuberculosis agents, Eur. J. Med. Chem. 39 (2004) 805-814; DOI: 10.1016/j.cjmech.2004.05.005.

8. V. Alagarsamy, R. Giridhar, M. R. Yadav, R. Revathi, K. Ruckmani and E. De Clercq, Anti HIV, antibacterial, and antifungal activities of some novel 1,4-disubstituted-1,2,4-triazolo [4,3-a]quinazolin-5(4H)-ones, Indian J. Pharm. Sci. 68 (2006) 532-535.

9. Y. Wang, G. Inguaggiato, M. Jasamai, M. Shah, D. Hughes, M. Slater and C. Simons, Synthesis and biological evaluation of novel 2'-deoxy-4'-thioimidazole nucleosides, Bioorg. Med. Chem. 7 (1999) 481-487; DOI: 10.1016/S0968-0896(98)00255-7.

10. C. O. Usifoh and G. K. E. Scriba, Synthesis and anticonvulsant activity of acetylenic quinazolinone derivatives, Arch. Pharm. Pharm. Med. Chem. 333 (2000) 261-266.

11. T. Singh, S. Sharma, V. K. Srivastava and A. Kumar, Synthesis, insecticidal and antimicrobial activities of some heterocyclic derivatives of quinazolinone, Indian J. Chem. 45B (2006) 2558-2565.

12. S. Drabu, A. Puratchikody, S. Munirajan and N. Kumar, Synthesis and pharmacological activity of some 2-substituted 4,5-diphenyl imidazoles, Indian J. Heterocycl. Chem. 16 (2006) 63-64.

13. I. J. Kuppast and P. V. Nayak, Anthelmintic activity of fruits of Cordia dichotoma, Indian J. Nat. Prod. 19 (2003) 27-29. 


\section{Sinteza i anthelmintičko djelovanje novih 2-supstituiranih-4,5-difenil imidazola}

SATYAJIT DUTTA

Refluksiranjem benzila s različitim supstituiranim aldehidima u prisutnosti amonijeva acetata i ledene octene kiseline sintetizirana je serija 2-supstituiranih-4,5-difenil imidazola (1a-j). Strukture sintetiziranih spojeva potvrđene su IR, ${ }^{1} \mathrm{H}$ NMR i masenom spektroskopijom. U testovima na anthelmintičko djelovanje određeno je vrijeme paralize 0,24 do 1,54 min i vrijeme smrti 0,39 do 4,40 min, dok standarni lijekovi albendazol i piperazin citrat imaju vrijeme paralize 0,54 i $0,58 \mathrm{~min}$, a vrijeme smrti 2,16, odnosno 2,47 min pri istim koncentracijama $(1 \%, m / V)$. Pet spojeva, 2-[2-hidroksifenil]-4,5-difenil imidazol (1b), 2-[3-metoksifenil]-4,5-difenil imidazol (1c), 2-[2-feniletenil]-4,5-difenil imidazol (1e), 2-[4-fluorofenil]-4,5-difenil imidazol (1g) i 2-[3-nitrofenil]-4,5-difenil imidazol (1h) pokazuju značajno anthelmintičko djelovanje u odnosnu na standardne lijekove.

Ključne riječi: 2-supstituirani-4,5-difenil imidazoli, anthelmintik, antiparazitik

Department of Pharmacy, IIMT College of Medical Sciences, 'O' Pocket, Ganga Nagar, Mawana Road, Meerut-250001, Uttar Pradesh, India 